\title{
KONSEP MURABAHAH DALAM PERSPEKTIF FIQH DAN PRAKTISI
}

\author{
NurFadillah
}

(90500120087)

Secara etimologis, murabahah berasal dari mashdar الريح yang berarti "keuntungan, laba, faedah"5. Wahbah az-Zuhaili memberikan definisi murabahah, Yaitu: "Jual beli dengan harga awal ditambah keuntungan"Murabahah didefinisikan oleh para Fugaha sebagai penjualan seharga Biaya/harga pokok (cost) barang tersebut ditambah mark-up atau margin keuntungan Yang disepakati. Karakteristik murabahah adalah bahwa penjual harus member tahu Pembeli mengenai harga pembelian produk dan menyatakan jumlah keuntungan yang Ditambah pada biaya (cost) tersebut. Dalam daftar istilah buku himpunan fatwa DSN (Dewan Syariah Nasional) Dijelaskan bahwa yang dimaksud dengan murabahah adalah menjual suatu barang Dengan menegaskan belinya kepada pembeli dan pembeli membayarnya dengan lebih Sebagai laba.

Murabahah adalah perjanjian jual-beli antara bank dengan nasabah. Bank Syariah membeli barang yang diperlukan nasabah kemudian menjualnya kepada Nasabah yang bersangkutan sebesar harga perolehan ditambah dengan margin Keuntungan yang disepakati antara bank syariah dan nasabah. Murabahah, dalam konotasi Islam pada dasarnya berarti penjualan. Satu hal Yang membedakannya dengan cara penjualan yang lain adalah bahwa penjual dalam.

Murabahah secara jelas memberi tahu kepada pembeli berapa nilai pokok barang Tersebut dan berapa besar keuntungan yang dibebankannya pada nilai tersebut.Keuntungan tersebut bisa berupa lump sum atau berdasarkan persentase.

Dalam murabahah dibutuhkan beberapa syarat, antara lain:

1. Mengetahui harga pertama (Harga PemMurabaha Pembeli kedua hendaknya mengetahui harga pembelian karena hal itu adlah Syarat sahnya transaksi jual beli.

2. Mengetahui besarnya keuntungan Mengetahui jumlah keuntungan adalah keharusan, karena ia merupakan Bagian dari harga (tsaman), sedangkan mengetahui harga adalah syarat Sahnya jual beli. 
3. Modal hendaklah berupa komoditas yang memiliki kesamaan dan sejenis, Seperti bendabenda yang ditakar, ditimbang dan dihitung Syarat ini diperlukan dalam murabahah dan tauliyah, baik ketika jual beli Dilakukan dengan penjual pertama atau orang lain. Serta baik keuntungan Dari jenis harga pertama atau bukan, setelah jenis keuntungan disepakati Berupa sesuatu yang diketahui ketentuannya, misalkan dirham atau yang Lainnya.

4. Sistem murabahah dalam harta riba hendaknya tidak menisbatkan riba Tersebut terhadap harga pertama Seperti membeli barang yang ditakar atau ditimbang dengan barang sejenis Dengan takaran yang sama, maka tidak boleh menjualnya dengan system Murabahah.

Jenis Murabahah dapat dibedakan menjadi 2 yaitu:

1. Murabahah tanpa pesanan Maksudnya adalah ada yang pesan atau tidak, ada yang beli atau tidak, Bank Syariah menyediakan dagangannya, penyediaan barang pada Murabahah ini tidak terpengaruh atau terkait langsung dengan ada tidaknya Pesanan atau pembeli.

2. Murabahah berdasarkan pesanan Bank Syariah baru akan melakukan transaksi murabahah apabila ada Nasabah yang memesan barang, sehingga penyediaan barang baru dilakukan Jika ada pesanan.

Rukun dalam murabahah secara garis besar terdiri dari tiga, sebagai berikut:

1. Pihak yang berakad

a.Penjual

b. Pembeli

2. Objek yang diakadkan

a. Barang yang diperjualbelikan

b. Harga

3. Akad/sighat

a.Serah (ijab)

b. Terima (qabul)

Imam Malik dan Imam Syafi'i mengatakan bahwa jual beli murabahah itu sah Menurut hukum walaupun Abdullah Saeed mengatakan bahwa pernyataan ini tidak Menyebutkan referensi yang jelas dari Hadis. Menurut al-Kaff, seorang kritikus Kontemporer tentang murabahah, bahwa para fuqaha terkemuka mulai menyatakan endapat mereka mengenai murabahah pada awal abad ke-2 $\mathrm{H}$. Karena tidak ada acuan Langsung kepadanya dalam al-Quran atau dalam Hadis yang diterima umum, maka para 
Ahli hukum harus membenarkan murabahah berdasarkan landasan lain. Malik Mendukung faliditasnya dengan acuan pada praktek orang-orang Madinah. la berkata "Penduduk Medinah telah berkonsensus akan legitimasi orang yang membeli pakaian Di sebuah toko dan membawanya ke kota lain untuk dijual dengan adanya tambahan Keuntungan yang telah disepakati. Imam Syafi'i menyatakan pendapatnya bahwa jika Seseorang menunjukkan sebuah komoditi kepada seseorang dan berkata: "Belikan Sesuatu untukku dan aku akan memberimu keuntungan sekian dan orang itu kkemudian Membelikan sesuatu itu untuknya, maka transaksi demikian ini adalah sah.

Wahbah az-Zuhaili mengatakan bahwa dalam jual beli murabahah itu Disyaratkan beberapa hal, yaitu :

\section{Mengetahui harga pokok}

Dalam jual beli murabahah disyaratkan agar mengetahui harga pokok atau Harga asal, karena mengetahui harga merupakan syarat sah jual beli. Syarat ini Juga diperuntukan bagi jual beli attauliyyah dan al-wadhi'ah.

\section{Mengetahui keuntungan}

Hendaknya margin keuntungan juga diketahui oleh si pembeli, karena margin Keuntungan tersebut termasuk bagian dari harga. Sedangkan mengetahui harga Merupakan syarat sah jual beli.

3. Harga pokok merupakan sesuatu yang dapat diukur, dihitung dan ditimbang,

Baik pada waktu terjadi jual beli dengan penjual dengan penjual yang pertama Atau setelahnya. 
Hadirnya bank syari'ah dewasa ini menunjukan kecenderungan yang semakin Baik. Produkproduk yang dikeluarkan bank syari'ah cukup bervariatif, sehingga Mampu memberikan pilihan atau alternatif bagi calon nasabah untukMemanfaatkannya. Dalam perbankan syari'ah, ada dua bentuk murabahah yang Umumnya dipraktekkan, yakni murabahah modal kerja dan murabahah investasi. Penjelasannya sebagai berikut:

1. Murabahah modal kerja

Adalah akad jual beli antara bank selaku penyedia barang dengan nasabah Selaku pemesan untuk membeli barang. Dari transaksi tersebut bank Mendapatkan keuntungan jual beli yang disepakati bersama. Atau menjual Suatu barang dengan harga asal (modal) ditambah dengan margin keuntungan Yang disepakati.

\section{Murabahah investasi}

Yaitu suatu perjanjian jual beli untuk barang tertentu antara pemilik dan Pembeli, dimana pemilik barang akan menyerahkan barang seketika sedangkan Pembayaran dilakukan dengan cicilan dalam jangka waktu yang disepakati Bersama.

Adapun rukun murabahah dalam perbankan adalah sama dengan fiqh dan Dianalogikan dalam praktek perbankan sebagai berikut :

1. Penjual (ba'i) dianalogikan sebagai bank.

2. Pembeli (musytari) dianalogikan sebagai nasabah.

3. Barang yang diperjualbelikan (mabi'), yaitu jenis pembiayaan seperti Pembiayaan investasi.

4. Harga (tsaman) dianalogikan sebagai pricing atau plafond pembiayaan.

5. Ijab Qabul dianalogikan sebagai akad atau perjanjian, yaitu pernyataan Persetujuan yang dituangkan dalam akad perjanjian.

Berdasarkan pembahasan tersebut di atas, dapat disimpulkan sebagai berikut:

1. Murabahah adalah salah satu produk yang dikembangkan oleh bank syari'ah. Produk ini didasarkan pada prinsip jual beli yang dalam istilah fiqh Islam Disebut dengan bai' almurabahah sebagaimana didefinisikan oleh ulama fiqh Adalah menjual barang dengan harga pokok ditambah dengan keuntungan yang Disepakati oleh kedua belah pihak. Bai' almurabahah ini merupakan salah satu Bentuk bai' al-amanah, disamping bai' at-tauliyyah, yakni menjual barang Dengan harga pokok tanpa mengambil keuntungan apapun dan bai'alwadhi'ah, Yakni menjual barang dengan harga jual dibawah harga pokok. 
2. Bai' al-murabahah dalam fiqh kemudian diterapkan dalam bentuk produk Perbankan syari'ah. Dalam perbankan syari'ah, produk ini diartikan sebagai Akad jual beli antara bank selaku penyedia barang dengan nasabah yang memesan untuk membeli barang. Dari transaksi tersebut, bank mendapatkan Keuntungan.

3. Aplikasi konsep murabahah dalam perbankan syari'ah ini menimbulkan

\section{DAFTAR PUSTAKA}

Az-Zuhaili, Wahbah. 1989. Al-Fiqh al-Islam wa Adillatuh, Jilid IV, Beirut: Dar al-Fikr. Departemen Agama RI. 1989. Al-Quran dan Terjemahnya. Surabaya: Surya Cipta

Aksara

Hendry, Arison. 1999. Perbankan Syari'ah: Perspektif Praktisi, Jakarta: Mu’amalat Institut

Munawwir, Ahmad Warson. 1997. Al-Munawwir, Kamus Arab-Indonesia, Cet. IV, Surabaya: Pustaka Progressif

Rahmawati, Anita. 2000. Kontroversi Konsep Murabahah Dalam Perbankan Syari'ah Dan Aplikasinya di BMI Semarang

Sabiq, As-Sayyid. Fiqh as-Sunnah, Jilid III. Beirut: Dar al-Fikr

Saeed, Abdullah. 2003. Bank Islam dan Bunga, Studi Kritis dan Interpretasi Kontemporer Tentang Riba dan Bunga, Terj. Muhammad Ufuqul Mubin, et. Al, Cet. I, Yogyakarta: Pustaka Pelajar

Wiroso. 2005. Jual Beli Murabahah, Yogyakarta: UII Press

Fatwa DSN MUI No. 04/DSN-MUI/IV/2000 Tentang Murabahah

Tazkiah Institute. Murabahah, Makalah disampaikan pada Lokakarya Perbankan Syari'ah, 14 Mei 1999. 